\title{
Discourses of Cultural Continuity among the Bakweri of Mount Cameroon National Park
}

\author{
Ayonghe Akonwi Nebasifu \\ University of Lapland, Finland \\ Ngoindong Majory Atong \\ University of Buea, Cameroon
}

\begin{abstract}
In recent years, the separation of people from their land through protected areas and conservation initiatives of local governance has been at the core of criticism in the people-park discourse. However, vital questions remain as to how people maintain cultural relations to parks and their peripheral zones. This paper explores circumstances where people are not entirely disconnected from their culture despite the state management of Mount Cameroon National Park (MCNP) in West Africa. In this example, people uphold subsistence activities and spiritual interaction with ancestors and deities steered under the umbrella of ritual beliefs. Based on an ethnographic inquiry among the Bakweri in the southwest region of Cameroon, we found that factors of remote settlement, an urge for collective assurances among people, and a sense of belonging in an ethnic group enhance a reciprocal attachment between people and place. This observation helps bridge gaps in people-park relations through cultural continuity.
\end{abstract}

Keywords: cultural continuity, ritual beliefs, Mount Cameroon National Park, Bakweri, West Africa

Résumé : Ces dernières années, la séparation des populations de leurs terres à travers les aires protégées et les initiatives de conservation de la gouvernance locale a été au cœur des critiques dans le discours peuple-parc. Cependant, des questions essentielles demeurent quant à la façon dont les gens entretiennent des relations culturelles avec les parcs et leurs zones périphériques. Cet article explore les circonstances dans lesquelles les gens ne sont pas entièrement déconnectés de leur culture malgré la gestion étatique du parc national du Mont Cameroun (MCNP) en Afrique de l'Ouest. Dans cet exemple, les gens soutiennent les activités de subsistance et l'interaction spirituelle avec les ancêtres et les divinités dirigés sous l'égide des croyances rituelles. Sur la base d'une enquête ethnographique menée auprès des Bakweri dans la région sud-ouest du Cameroun, nous avons constaté que les facteurs d'installation à distance, le besoin d'assurances collectives parmi les personnes et le sentiment d'appartenance à un groupe ethnique renforcent un attachement réciproque entre les personnes et le lieu. Cette observation aide à combler les lacunes dans les relations entre les personnes et les parcs grâce à la continuité culturelle.

Mots clé : continuité culturelle, croyances rituelles, Parc National du Mont Cameroun, Bakweri, Afrique de l'Ouest

Ayonghe Akonwi Nebasifu is a member of the Anthropology Research Group with the Arctic Centre at the University of Lapland. Ngoindong Majory Atong is a social anthropologist with the Department of Sociology and Anthropology at the University of Buea. Email: aayonghe@ulapland.fi

Culture and Local Governance / Culture et gouvernance locale, vol. 6, no. 2, 2020. ISSN 1911-7469

Centre on Governance, University of Ottawa, 120 university, Ottawa, Ontario, Canada K1N 6N5 


\section{Introduction}

Forestlands in Africa are crucial to the livelihood of local people. For this reason, the 1986 African Charter on Indigenous Rights to Land protects the occupancy of ethnic groups on the land (ACHPR and IWGIA, 2005). All the same, the need to respect indigenous rights to land became critical in the 1980s when the International Union for Conservation of Nature (IUCN) realized that humans contributed to biodiversity loss. Given the importance of maintaining forestlands, African institutions continue seeking options for people to use forests in sustainable ways. Cameroon, in particular, adopted the 1992 UN Convention on Biological Diversity, intending to address conservation and promote the needs of indigenous people living in and around protected areas. On the example of Cameroon, most protected areas are managed under stateled systems of resource governance. Although collaborative initiatives are gradually being introduced, previous analysis indicates that such measures have lapses in their procedures of participation (Nebasifu and Atong 2019a, 2019b). Thus, important questions remain as to whether cultural practices persist regardless of this situation.

Given the importance of indigenous knowledge in sustaining biodiversity, it is discouraging that studies in the people-park discourse indicate little success in steering African communities towards the attainment of conservation objectives (Muhumuza and Balkwill, 2013; West et al., 2006). These studies also refer to the intensification of human activities on forestlands. For instance, Joppa et al.'s (2008) analysis of 'paper parks' in the Congo Basin of Africa conveyed the damaging impact of roads, logging, and forest fires on biodiversity. Hartter's (2007) report on Kibale National Park in Uganda portrayed how landscape development affects the livelihood of forest people and the maintenance of natural land. In these circumstances, people who for many generations settled on the land become 'victims of change', in what West et al. (2006) described as changing land-use rights and cultures of people.

There are, however, examples of the proper use of forestlands which we need to acknowledge. In the case of Africa, Appiah-Opoku (2011) observed that local people innovatively use Kakum National Park in Ghana to sustain both biodiversity and their livelihood through ecotourism. Taubert and Pretzsch (2007) examined how elders of the Tiriki clan managed the Kakamega sacred forests in Kenya through practices of circumcision and initiation. Here, the Tiriki elders prohibit the felling of trees, wood, and sharing of secrets about initiation to women, children, and strangers. Similarly, local people effectively use the Muzarabani dry forests of the Zambezi valley in Northern Zimbabwe for burial while preventing changes in the landscape (Byers et al., 2001). They believe that a flame thorn plant (Acacia ataxacantha) provides thick dense vegetation to keep evil witches away from disturbing bodies of the dead.

Even so, broader cases in South Asia, Canada, and Australia indicate good examples where indigenous cultural practices are recognized as park activities. Pastoral nomads who inhabit the Margallah Hills National Park in Islamabad, Pakistan, enjoy the huge benefits of gathering its rich medicinal plant resources for their food, fodder, health care, fuelwood, and other cultural needs (Jabeen et al., 2009). Indigenous communities in Canada are increasingly taking a lead in restoring their rights to indigenous lands, through a model known as Indigenous Protected and Conserved Areas (IPCAs). The model enables them to support ecosystems and land-use in ways that safeguard indigenous rights and responsibilities to manage traditional territories (Plotkin, 
2018; Zurba et al., 2019). This has enabled First Nations groups like the Tla-o-qui-aht to create Tribal Parks in British Colombia. Similarly, in Australia, the state-following its commitment to promote new Indigenous Protected Area (IPA) initiatives in 2017-has enabled indigenous communities to plan, govern, and protect the cultural importance of existing national parks for future generations (Rist et al., 2019). Although the above examples are important for recognizing the respect for customs in parks, further investigations are needed to understand how local and indigenous people continue to practice their culture in spite of state restrictions for local land users. The absence of literature on such cultural continuity makes it hard to suggest alternative ways of enhancing people-park relations.

\section{The Mount Cameroon area}

To bridge this gap, we explore cultural narratives of the Bakweri residing in the Mount (Mt) Cameroon region of sub-Saharan West Africa. The mountain (also known in Bakweri as Mount Fako) and adjacent villages are located between latitude $4^{\circ} \mathrm{N}$ and longitude $9^{\circ} \mathrm{E}$ of the equator, covering about 58,178 hectares of land concerning protected territories. The site has both a dry season that lasts close to 4 months, between January and April, and a wet season of approximately 5 months, between June and October, though these seasonal durations tend to fluctuate with the influence of climate change. Both seasons provide alterations from sunshine to rainfall ranging from approximately 2,000 to 10,000 millimetres during the year, and temperatures of between $4^{\circ} \mathrm{C}$ and $32^{\circ} \mathrm{C}$, making it favorable for rich vegetation growth. $\mathrm{Mt}$ Cameroon stands at an altitude above 4000 meters, making it the highest peak in sub-Saharan West Africa. Mt Cameroon is also home to several wildlife species (such as bats, drill, Preuss's guenon, forest elephants, antelopes, Nigerian-Cameroon chimpanzees, and a variety of birds) that are threatened by anthropogenic factors of illegal hunting, bush fires, logging, and the expansion of plantation agriculture.

The mountain is a site of ancestral heritage for the Bakweri. Its park is crucial not just for preserving biodiversity, but for the Bakweri inhabiting some of the 41 villages surrounding the park together with other cultural groups that rely on forest resources for livelihoods. For this reason, state authorities encourage the sustainable use of community forests that surround $\mathrm{Mt}$ Cameroon-e.g., the Bakingili and Woteva community forests that local communities use for subsistence farming, collection of fuelwoods, and timber exploitation (Ngang et al., 2018). Because conservation seems to coincide with local needs, there is an urgent need to investigate whether cultural practices can endure under this system. The Bakweri live among other groups like the Oroko, Bakossi, and Banyangi, to name a few, whose everyday life deeply connects to the use of the coastal forest to secure food, medicine, and water (streams, rivers, and the sea) for fishing. Their reliance on the forest, together with the extension of banana and oil palm plantations managed under the Cameroon Development Corporation (CDC), presents a threat to sustaining biodiversity in the Mt Cameroon region. This is why the state has adopted a number of laws for governing the land-e.g., the 1974 land tenure law in Cameroon provides that the government can declare portions of national lands (those not visibly settled, cultivated, or registered with a domain) to be the 'private property of the state' (Wily, 2011). 
The state forest law of 1994 restricting the exploitation of certain resources in protected areas backs the 'private' mode of land ownership by the state. The 1994 forest law lies at the core of park management, as it regulates the customary rights of the Bakweri to exploit forest products meant for home consumption, including non-timber forest products like herbal plants and wild honey. The law also groups animals into categories to reduce poaching; for example, category (A) animals are endangered species like monkeys, chimps, elephants and mandrills, strictly prohibited from hunting in and around protected areas (Republic of Cameroon, 1994). To ensure the preservation of biodiversity on Mt Cameroon, the government created Mount Cameroon National Park (MCNP) in 2009 (Figure 1), as part of a measure to fulfill its commitment to the 1992 UN Convention on Biological Diversity. MCNP falls under the IUCN category II protection status and has over 2,435 plant species, of which 49 are endemic to Mt Cameroon (Charlotte, 2014). Plant examples include Agauria salicifolia (Mbeli in Bakweri), Strangler fig (Ficus spp), mountain flower (Helichrysum mannii), Adenocarpus mannii, and Crassula vaginata, to name a few. MCNP is one of the eight biodiversity hotspots in the Gulf of Guinea Forests, West Africa. Its western slope is the only site in West and Central Africa where an unbroken vegetation gradient exists from evergreen lowland at sea level, to montane forest, montane grassland, and alpine grassland close to its summit. 


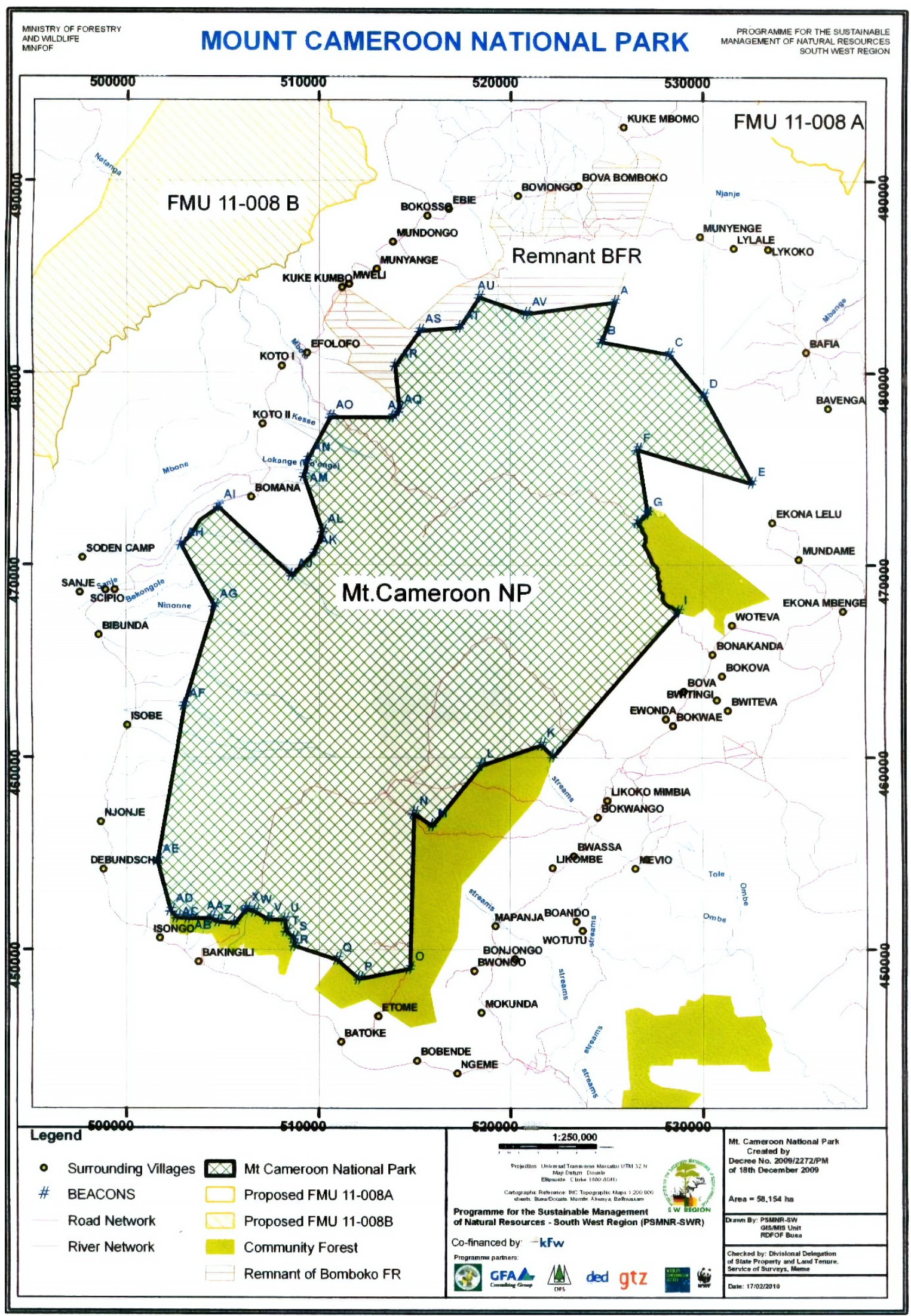

Figure 1: MCNP and surrounding villages. Adapted from MCNP Service in 2017. 
A governing body, MCNP Service performs tasks in collaboration with local communities through a system of co-management to monitor and assess the effectiveness of resource management in villages, implement conservation development agreements, issue conservation bonuses (remunerations), gather feedback from locals, as well as involve institutions (government and private) from various levels of society in park management. The state collaborates with various stakeholders at local, sub-divisional, regional, and national levels through a Program for the Sustainable Management of Natural Resources in the Southwest Region of Cameroon (PSMNR-SWR) to ensure effective park management (Nebasifu and Atong, 2019a). For instance, during the last decade, MCNP received technical support from the Deutsche Gesellschaft für Internationale Zusammenarbeit (GIZ) and the World Wildlife Fund (WWF), and financial assistance from the German government through the German development bank Kreditanstalt für Wiederaufbau (KFW) (Nebasifu and Atong, 2019a, 2019b).

\section{Bakweri culture}

Various narratives exist about the origins of the Bakweri and their early settlements in the Mt Cameroon area. What appears common in the literature is that the Bakweri migrated from elsewhere and settled along coastal areas of the southwest and littoral regions of Cameroon where they engaged in hunter-gathering and ritual practices, though such practices are shifting to incorporate modern forms of agriculture, land-use, and religious beliefs. Neh (1989), for instance, noted that the Bakweri came from the great lakes between the Nile and the Congo in the period of $400 \mathrm{BC}$, from which they split into groups: some settling in East Africa and Southern Africa, and others in Cameroon. Here, the word Vakpeli (meaning "those who have settled") in Mokpwe (the language of the Bakweri) pertains to a common narrative about descendants from an older race known as 'the Bombokos' who came from a place called Bomboko, northwest of Mt Cameroon, where a small group of the Bakweri settled. From Bomboko, Eye Njie, a man who led the group, left and formed the place Buea (Neh, 1989). From this perspective, other narratives relate to scattered settlements, wherein isolated groups from Bomboko moved to the river Mungo, others continued through the creeks to reach Duala, and some mixed with the coastal people of Limbe and the Mboko, until the colonial era when many of them were forced into densely packed villages. The Bakweri are also referred to as one of the seven Bantu-speaking tribes (the others being Balong, Bamboko, Bakolle, Mongo, Wovea, and Isubu) in coastal Cameroon due to similarities in their spoken language (Ardener, 1996, p. 227).

In the 1880s, following Ardener's encounter with the Bakweri on Mt Cameroon, he described them as people who lived in the lowland forests of Mt Cameroon, where they had settled in huts roofed with grass and lit with fire in the middle, and from where they often walked to higher heights of grassy plains on the mountain to hunt antelopes both in the mornings and evenings. They did so by hiding behind rocks and hills before shooting the animal. He noted that the hunters were quick in their hunt, with many of them visiting the grassy plains at higher altitudes of the mountain for food. They were skillful, tracing steps of antelopes and being able to predict their resting place for that day. The Bakweri rarely spent more than a week in the grassy plains because their lungs could not withstand the cold winds. They equally believed that Loba (Bakweri's god on the mountain) had no desire for the hunters to cross 'his 
home' (Ardener, 1996, pp. 25-27). Some of the deaths of hunters from cold were thus perceived as a consequence of not respecting Loba. This is one of the historical signs of animist religion among the Bakweri. Ardener talked about Loba, whom nobody gets to see, living above the peak of Mt Cameroon; yet Loba is present and moves everywhere, faster than men think (pp. 101107). He governs the thunder, sun, and moon, and kills the wicked. Loba has two sons: Ovasse imparts good across the land, and Mokasse uses the crater on the mountain to torture the wicked and has evil spirits that assist him. Further, the Bakweri had witch-men-persons specially gifted to bewitch fellow-creatures-make them sick and kill them or protect them from sickness and death.

Nowadays, the Bakweri practice their animist beliefs alongside Christianity. Many of the early scattered settlements have become dense in semi-urban and rural areas. While many of those living in the districts of Buea, Limbe, Muyuka, and Tiko adopt skilled professions in educational and business sectors, the rural Bakweri maintain close ties with the forests, working as hunters and farmers growing a variety of crops such as cocoyam, plantains, oil palm, cassava, and maize, considering the high fertility of Mt Cameroon's volcanic soil. In terms of sociopolitical organization and settlement, the Bakweri are grouped into villages where family units are independent, comprising the father, his wife (or wives), kids, and relatives with blood ties. Here, the father, as head of the family, presides over matters of the family and might consult with elderly people in the family lineage before making important decisions.

Kinship is patrilineal, such that the eldest son inherits the father's property upon his death, although this might depend on the son's behavior. In situations where the son is arrogant or disrespectful to elders, inheritance could be offered to the brother or a trustworthy family member. Administratively, a chief takes the leadership role in a village with the aid of a council of elders (traditional councils) to regulate village affairs. When it comes to land ownership, it can be acquired through inheritance. Persons from elsewhere can also buy land from Bakweri families in a village, but this must be done with the knowledge of the traditional council. In other cases, land required for development projects with a purpose to serve the entire community can be provided with the facilitation of the traditional council, though this approach could at times be altered by state law for land ownership (Wily, 2011), in addition to village committees that partake in deciding important affairs about the village. One of the prominent Bakweri chiefs, Kuva Likenye, is much respected for leading Bakweri warriors in clashes against German military raids in the 1890s when he held up a strong veto on the foreign exploitation of $\mathrm{Mt}$ Cameroon (Ardener, 1996).

Anthropologically speaking, maintaining a connection between ancestral spirits and the world of the living is crucial for the Bakweri culture. Here, the forest and its resources, such as trees, animals, water and various sites of nature, are perceived to hold spiritual power that can be utilized by certain individuals of the Bakweri to shape events in the living world. Consider a previous report by Ardener (1996, p. 243), referring to the Bakweri as economically marginalized people who turned to witchcraft (also known as nyongo in Mokpwe) to escape sociocultural crises brought on by colonial agriculture. The Bakweri believed that individuals with nyongo had powers to cause the death of relatives working for colonialists in plantations. Ardener (1996) noted that such belief was rooted in the minds of people who presumed anyone showing signs of wealth and benefit from colonial agriculture had nyongo and belonged to an association of 
witches. Akem (2019, p. 2286) provides an interesting perspective on the spiritual link between people and what he called 'lesser creatures', plants and animals. Based on this concept, the Bakweri keenly appreciate the forest for having a supernatural force that controls lesser creatures existing as 'totems' of individuals, clans, and villages on the land-perceived as having the ability to execute desires of the human host, such as rescuing drowning men in the sea and raiding farms in acts of vengeance. For this reason, the Bakweri use 'secret forests' (e.g. Bova, Bonakanda, and Bokwango secret forests) enforced by cults that instill fear of punishment by death or exile from the village for any unauthorized activity in such forests, to ensure forest protection and keep intruders from causing disturbances.

In this sense, the forest lies at the center of Bakweri culture. It is a place to seek help from ancestors in conducting everyday life activities. It is also a source of food, peace, and refuge from foreign aggressors. How the Bakweri accomplish such needs amid state restrictions on the land remains questionable, bearing in mind that their history included conflicts with colonial authorities, and subsequently, with state authorities, over matters of land-use and ownership. In the 1890s, for instance, German colonialists confronted the Bakweri, leading to their displacement from the slopes of Mt Cameroon-lands they formerly inhabited now used for plantation agriculture (Pemunta, 2018). Years after that, land acquisition, use, and accessibility in the Mt Cameroon area increasingly became an issue of state governance to conserve biodiversity. In 2009, the state created MCNP (previously a Bakweri native land), adapting measures prohibiting unauthorized entry to the park, using both stipulations of the 1994 forest law, and later, a co-management framework to enable local communities to develop alternative means of livelihoods and comply with state laws to curb illegal hunting.

There are, however, lapses in the state's model for managing MCNP. According to Nebasifu and Atong (2019a; 2019b), though the current system for resource management created forest management committees through which local people participate in the state's agenda for resource management, the system adopts mechanisms such as Conservation Development Agreements (CDA) that do not completely give space for people to exert their customary rights to use protected areas. This leads to expressions of grievance among farmers who lost portions of their land to state authorities during park boundary adjustments and locals unhappy with a regime that does not meet its development promises. Therefore, we show that despite state prohibitions in the conservation of MCNP, there are occurrences where people continue to use the land in ways consistent with their culture. To do so, we examine (a) the relationship between the land and individual narratives about ritual beliefs, (b) how these narratives shape the nature of cultural continuity, and (c) factors that influence the attachment of people to the land despite state measures for governing MCNP and adjacent villages.

\section{Materials and Methods}

We made a visit to Cameroon between September and December 2015 to familiarize ourselves with problems in the MCNP area, and later in 2017 for fieldwork. We used the ethnographic method of focus group interviews to collect data among individuals of the Bakweri in the year 2017 (Figure 2 and Figure 3). 


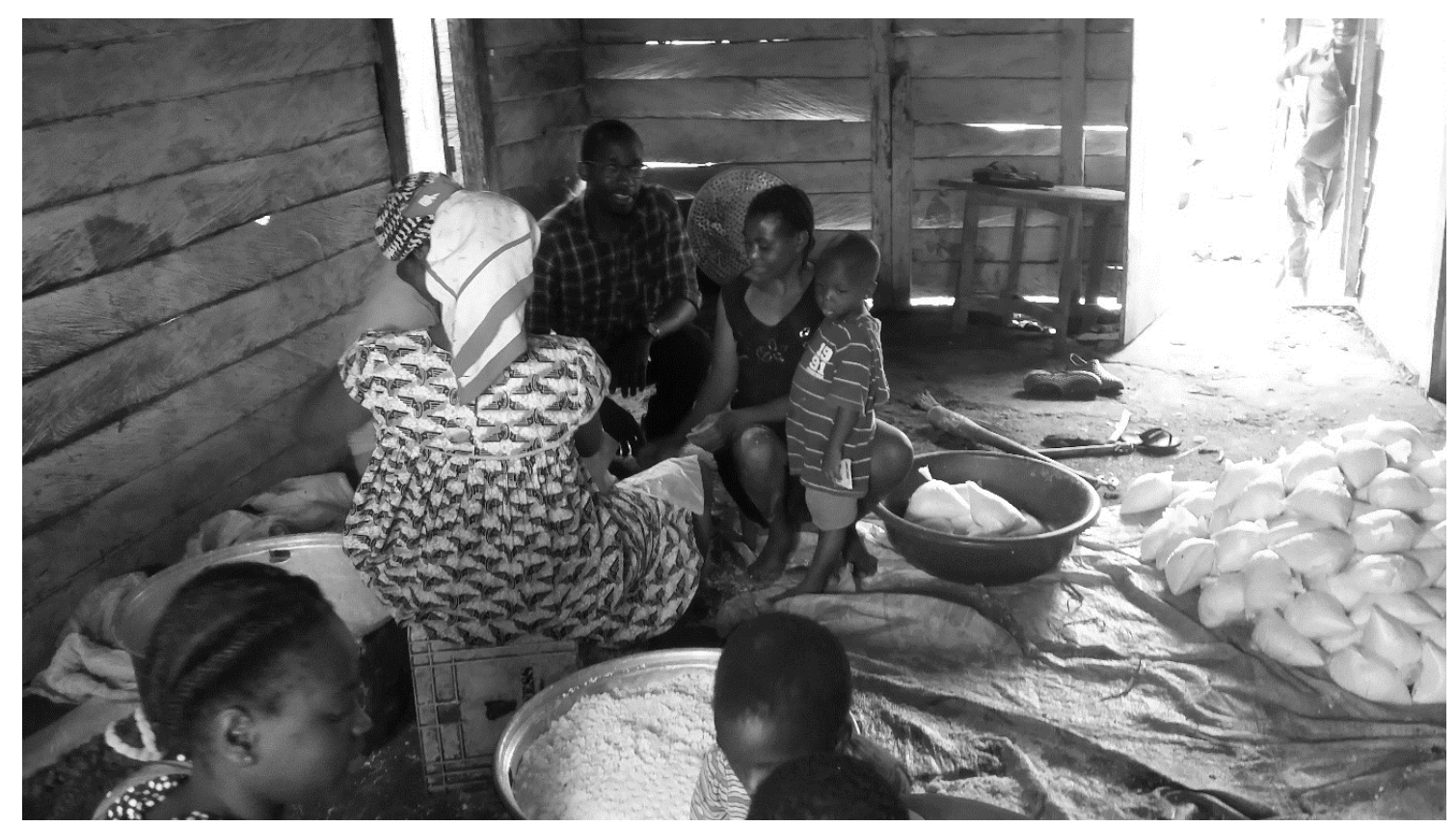

Figure 2: Meeting with farmers at Boviongo. The authors' field data gathered in 2017.

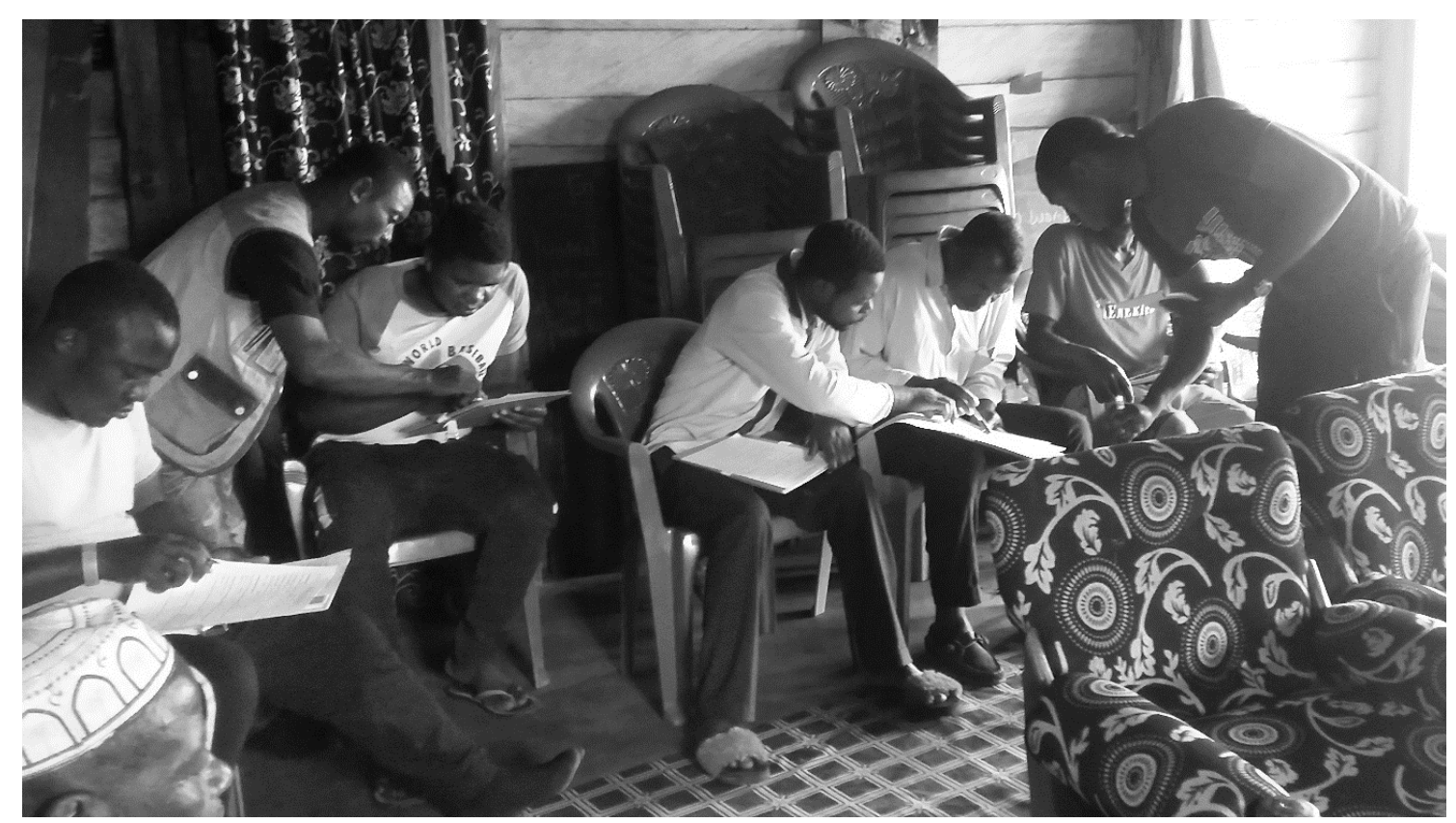

Figure 3: Conducting interviews at Munyange. The authors' field data gathered in 2017.

According to Doody et al. (2012), focus groups help researchers disclose knowledge uncovered by other methods of data collection. Consistent with this view, we reviewed unpublished data obtained from the MCNP office in Buea, targeting assessment and monitoring reports written between 2009 and 2016 by park officials, for the 41 villages around MCNP. Using this data, we were able to determine villages associated with the use of forests. To identify villages in contact with the park, we adopted Maxwell and Miller's (2008, p. 462) principle of 
'similarity-contiguity' by using three categories with similar attributes (Table 1). Based on this categorization, we chose 17 villages for our study (Table 2).

Table 1: Employing Maxwell and Miller's (2008) similarity-contiguity approach.

\begin{tabular}{ll}
\hline Category & Similar attributes for study villages \\
\hline $\begin{array}{l}\text { Villages located between } 1 \mathrm{~km} \text { and } 12 \\
\text { km from the park boundary. }\end{array}$ & $\begin{array}{l}\text { Villages closer to park boundaries have greater } \\
\text { likelihood of interaction with protected areas. }\end{array}$ \\
$\begin{array}{l}\text { Villages with dominantly Bakweri } \\
\text { people. }\end{array}$ & $\begin{array}{l}\text { Villages have shared beliefs and rituals relate to the } \\
\text { land. }\end{array}$ \\
$\begin{array}{l}\text { Villages associated with livelihoods of } \\
\text { hunting, timber exploitation, and } \\
\text { farming. }\end{array}$ & Villages have traditional practices of life support. \\
\hline
\end{tabular}

Table 2: Distribution of study villages. Adapted from Nebasifu and Atong (2019b).

\begin{tabular}{lllll}
\hline $\begin{array}{l}\text { Cluster } \\
\text { conservatio } \\
\text { nzones }\end{array}$ & Study villages & $\begin{array}{l}\text { Estimated population } \\
\text { size (individual } \\
\text { persons) }\end{array}$ & $\begin{array}{l}\text { Approximate } \\
\text { distance of village } \\
\text { from MCNP (km) }\end{array}$ & $\begin{array}{l}\text { Participants } \\
\text { per village }\end{array}$ \\
\hline Buea & Bonakanda & $1000-1500$ & $1-6$ & 16 \\
& Lower Boando & 500 & $6-12$ & 16 \\
& Batoke & $>2000$ & $1-6$ & 16 \\
& Bakingili & $>2000$ & $1-6$ & 16 \\
& Njonje & $<1000$ & $1-6$ & 16 \\
& Bibunde & $>2000$ & $6-12$ & 14 \\
& Sanje & $500-1000$ & $6-12$ & 16 \\
Muyuka & Lykoko & $>2000$ & 12 & 16 \\
& Munyenge & $>2000$ & $6-12$ & 16 \\
& & & $1-6$ & 16 \\
Bomboko & Bomana & $1000-1500$ & $1-6$ & 16 \\
& Big Koto I & $1000-1500$ & $6-12$ & 16 \\
& Efolofo & $500-1000$ & $1-6$ & 16 \\
& Kuke Kumbo & $1000-1500$ & $6-12$ & 16 \\
\hline Total & Munyange & $500-1000$ & $6-12$ & 16 \\
\hline
\end{tabular}


With the assistance of park officials, cluster facilitators, and village chiefs, we selected local groups (informal and formal) in 17 villages and assigned individuals for focus group discussions (FGD). The individuals were local farmers, hunters, and traders who participate in comanagement initiatives for MCNP and adjacent communities. Formal groups were those endorsed by the government in collaboration with village inhabitants; meanwhile informal groups were groups overly recognized by the locals (Table 3 ).

Table 3: Description of focus groups. Adapted from Nebasifu and Atong (2019b).

\begin{tabular}{|c|c|c|}
\hline Group & Type & Task \\
\hline $\begin{array}{l}\text { Village Forest Management } \\
\text { Committee }\end{array}$ & Formal & Organize meetings on park management \\
\hline Vigilante Group & Informal & Look after the safety of persons in the village \\
\hline Hunters Group & Informal & $\begin{array}{l}\text { Carry out joint hunting and distribute } \\
\text { revenue from hunting }\end{array}$ \\
\hline Village Development Group & Informal & Promote the wellbeing of village inhabitants \\
\hline Farmers Group & Informal & $\begin{array}{l}\text { Plan and share benefits from farming } \\
\text { activities }\end{array}$ \\
\hline Health Committee & Formal & Intervene on matters of health \\
\hline Quarter Heads & Informal & Lead sub-groups of people in a village \\
\hline Traditional Council & Informal & $\begin{array}{l}\text { Advise chiefs on matters of a land dispute in } \\
\text { a village }\end{array}$ \\
\hline
\end{tabular}

Each focus group comprised 16 participants, except Bibunde due to the absence of a Vigilante Group (Table 2). FGDs were on average close to two hours in length and took place between 9 a.m. and 1 p.m., although we encountered several delays during this process. The lead author moderated the meetings with the help of a research assistant who recorded interviews and cluster facilitators who assisted with translation. The languages of communication during discussions were Mokpwe and Pidgin English.

To administer interviews, we used an interview guide targeting the demographic traits of respondents, local opinions about the state management plan for MCNP, and narratives about ritual practices on the land. Demographic traits were made of close-ended questions about the date and time of the interview, gender characteristics, list of village groups and a Likert scale of age levels (between 16 and 60+). We applied a discourse analysis based on the descriptions of Doody et al.'s (2012) 'six-step data analysis' for focus group interviews (Table 4) to collect quotations, demonstrating how experiences of people and events arise in a discourse. 
Table 4: Using Doody et al.'s (2012) six-step data analysis for FGD

\begin{tabular}{|c|c|c|}
\hline Number & Step description & Authors' use \\
\hline 1 & Generating rich data & $\begin{array}{l}\text { We interviewed both formal and informal groups to obtain } \\
\text { diverse explanations about the use of forestlands. }\end{array}$ \\
\hline 2 & $\begin{array}{l}\text { Familiarising one's self } \\
\text { with the data }\end{array}$ & $\begin{array}{l}\text { We employed cluster facilitators to assist us in } \\
\text { translating/interpreting the various text in Mokpwe. }\end{array}$ \\
\hline 3 & Writing memos & $\begin{array}{l}\text { We kept a record of Mokpwe words about rituals and beliefs } \\
\text { on the land. }\end{array}$ \\
\hline 4 & Indexing & - \\
\hline 5 & Formation of themes & $\begin{array}{l}\text { We raised questions about names of sacred sites, cults, and } \\
\text { the reciprocal use of land. }\end{array}$ \\
\hline 6 & $\begin{array}{l}\text { Mapping and } \\
\text { interpretation }\end{array}$ & $\begin{array}{l}\text { We identified conditions that influence local attachment to } \\
\text { place. }\end{array}$ \\
\hline
\end{tabular}

\section{Results}

For us to understand the cultural continuities among the Bakweri, we need to make a differentiation between two types of land. The locals perceive MCNP as 'government land' and peripheral zones of the park (communal land and community forests) as 'village land'. In both types of land, the Bakweri practice rituals and gather forest products of all kinds. This is not to say that similar activities occur in all surrounding villages of the park. The structure of the landscape and vegetation differ significantly between villages in remote areas and those in semiurban areas. These disparities offer a varied knowledge of how people use the park and its peripheries. Our results should therefore not be generalized to the entire Bakweri ethnicity. In the subsequent paragraphs, we use words adopted from Mokpwe to present the narratives of cultural continuity.

\section{Ritual beliefs}

The Bakweri regard deities and ancestral spirits as vital to everyday life (i.e. in guarding the land and promoting prosperity in society). Consistent with the views of Ajonina et al. (2017), our interviews pointed out that despite state plans that limit the access of local people to MCNP, individuals of the Bakweri maintain relations with their ancestors and deities through sacred societies and cults. In this situation, taboos reinforce Bakweri traditional beliefs and are punishable upon violation-for example, by casting spells that require ceremonial cleansing for curing. According to folkloric narratives told by respondents, certain animals like the African forest elephant, whiteface owl, and python are rarely touched for fear that they carry spirits of the deceased. In this tradition, felling certain trees or killing particular animals only occurs after ritual consultation with deities. For this reason, ritual practices remain essential for many people, with regards to cultural continuity on government land and village land. What makes this form of knowledge valuable is that it is often undeclared for individuals who are keen to continue using the forest. 
Our interviews with focus groups stated that persons among the Bakweri have knowledge of certain sites in the park and its peripheral forests used for ritual activities. As such, the biological diversity of such sites benefits from protection. For example, village elders make sacred incantations to consult the dead. A member of the Traditional Council talked about the use of forestland for Nyangkpwe in a ritual activity aimed at cleansing and protecting villages from external hostilities. The Nyangkpwe cult symbolizes a pathway for the traditional cleansing of villages with the help of ancestral spirits. This is similar to the case of Lykoko where a participant talked about a religious cult, $l k p e$, as a unit that prevents violent confrontations between villages. In these examples, people hold onto their culture for security reasons.

The Bakweri possess a prominent ritual known as Maale, a tradition rooted in Bakweri ancestral tradition and practiced in remote forests during particular months of the year. They maintain the Maale ritual, as a member of the Farmers Group remarked: "We use the park and other forests to locate our shrines. We use Isuma cave and a red hill in the forest for Maale" (Field data, 2017).

The interviewee above recognizes Maale ritual as a traditional event that takes place within the forest, though in specific times of the year in secrecy among members of the Maale cult. The Maale ritual uses sacred sites (caves and hills) in remote forests on both village and government land. Another respondent in the Hunters Group refers to the use of huts known as the Mohoko juju house in peripheral zones of MCNP, which traditional doctors (Gahga yowo) use occasionally for witchcraft, healing, and to contact ancestral spirits.

Local narratives about the origin of Maale ritual seem rather diverse with different stories told by the people. A member of the Hunters Group maintained that:

A hunter from Womboko (a nearby village to Mount Cameroon) went hunting in a forest and was later announced dead. Unexpectedly, he returned to the village, recounting his contact with ancestral spirits who taught him secrets of the forest and how to transform into an elephant. When village elders consulted the ancestral spirits to verify his story, they found that the spirits confirmed the hunter's narrative to be true. This confirmation urged village elders and hunters to initiate themselves: a process that required animal sacrifices, prayers and pouring of libation in the forest. Men exclusively performed this ritual. (Field data 2017)

Elephants have a symbolic role in the Maale cult. They represent totems from which the Bakweri extract spiritual powers to protect villages from external hostilities. Male members of the Maale cult mimic such powers by illustrating the strength of Bakweri men through ritual dances where the men dress as elephants (Njoku). The word Njoku, in Mokpwe, refers to African forest elephants believed to keep ancestral spirits crucial to alter life events among the Bakweri. This is why Bakweri traditional norms protect African forest elephants from being hurt. A hunter from the Hunters Group indicated that this belief system partly influenced improvements in the elephant population on MCNP over the last decade, adding to the efforts of park management authorities.

The interviews indicated practices of belief in several spiritual beings. For example, the 'god of the mountain' (Efassa moto) was a relevant case where people worship the being for 
reciprocal need. When we asked respondents about the worship, they explained that sacrifices and pouring of libations were important gestures to request peace and protection of the village from Efassa moto. A member of the Traditional Council stated: "There exists incantation where the elites go to the forest to appease the gods in case any problem arises like rapid dryness of streams and rampant deaths in the community" (Field data, 2017).

Along the lines of this quotation, the Bakweri see Efassa moto as a spiritual force on the mountain that can prevent volcanic eruptions, earthquakes, and other disasters. By using powers from this spiritual being, the Bakweri gain sacred knowledge of how to cause rainfall during lengthy seasons of dryness and little crop growth.

This perception was similar to the response of a member of the Village Development Group who spoke about a river ritual (Liwangi bakundu) in Bomboko. According to Bakweri belief, women perform the river ritual around water catchments to request spiritual intervention to enhance body fertility for childbirth. According to the respondent, Liwangi bakundu occurs under the guidance of ritualists (Sango y a bando) who possess the skill of communicating with spirits to mediate this process. A respondent of the Health Committee indicated that: "During this event, women rub a white stone gotten from water catchments (calaba chalk) on their bodies and walk along the water at night" (Field data, 2017).

We see in the above example how the need for life support influences cultural continuity on the land. In Bakingili, a member of the Village Forest Management Committee talked about the role of the Bakweri as custodians of the sea, what he described as their task of caring for the sea in expectation of peace and fortune from the goddess of the sea (Liengu-la-mwanja). Based on Bakweri belief, Liengu-la-mwanja relates to the Liengu cult, also known among the Bakweri as 'deep water'. This cult retains the highest connection with water spirits and symbolizes a rite for both men and women to consult the sea goddess to cure complex diseases. A participant from the Quarter Heads group explained that:

The formation of Liengu cult comes from the story of a woman known as Liengu, who contested with a man known as Moto, over an issue of who could make the biggest fireside on the land. When Moto won the contest, the villagers forced Liengu to flee to the sea where she never returned. (Field data, 2017)

Based on the above narrative, in the Liengu ritual, when a rare illness infects a woman, other women take the infected individual to a fireplace with three stones and dress her with roots from an Iroko tree. A traditional doctor (Gahga yowo) comes in, makes her faint, and addresses her in a secret Liengu language. The Gahga yowo then invites drummers and gives some medicine to the infected woman, which she later vomits, after waking up, to symbolize the healing process. The Bakweri keep the information about the ingredients of the plant medicine a secret part of the cult. They maintain such rituals to support the life of people in critical situations of sickness.

In spite of cultural continuities on the land, there were a few barriers, mainly due to the state prohibiting the unauthorized entry of village inhabitants into the park. Many of the respondents we interviewed were skeptical of these restrictions on the land. In Bonakanda, a member of the Farmers Group irritably said in Pidgin English: "Sheep, salt, oil for go make prayer for up Mountain make fire no come down. Make them leave people to go up" (Field data, 2017). 
In this quotation, the individual expresses dissatisfaction with park officials who prevent locals from entering MCNP regularly for ritual purposes. He goes further, insisting that on such occasions the locals must regularly take sheep, salt, and palm oil to the mountain for rituals during the year without any state obstruction. Furthermore, he stresses the necessity of making appeals to Efassa moto to prevent the destruction of farm crops by a lava flow from the mountain.

\section{Signs of subsistent land-use}

One of our elderly informants during group discussions in Efolofo village told us that the locals have deeply rooted ties with the park where they collect the mushrooms, njangsa, ngongo leaf, fruits, and wild honey needed for food and essential nutrients. Nearby forests are an important source of materials acquired for constructing most of the wooden houses (karabot). Other examples, which were mostly non-timber forest products, that the respondent listed as a collected resource from the park included monkey cola, oil palm, alligator pepper, bush pepper, bush onion, wrapper leaves, bush mango, and wild vegetables like Gnetum africanum, which are commonly used for household consumption.

Another important resource the locals harvest from peripheral forests of the park is charcoal-a domestic fuel extracted to cook food and keep houses warm during chill weather. We were told the locals do the harvest by putting logs on the fire in a controlled manner to ensure the fire is put out before it burns out entirely, and then collecting the substance charcoal. Charcoal is equally a lucrative product in high demand from cocoa producers, restaurant operators, and fishermen who need supplies for their day-to-day businesses. In a discussion with one of the locals in the Hunters Group (see table 3), we were informed about the hunting of bushmeat (such as mole rats), from holes in the forest, using lighting fires on the holes beneath the ground and smoking them. This enables the rat to exit the hole into a man-made trapped box.

The harvesting of plants mainly for medicinal, ritual and household needs in community forests are a further example of the subsistence use of land. Plants like Mahogany and Iroko are major sources of firewood to villagers. A member of the Village Development Group noted that he used the extracts of camwood to enhance the fertility of a newly wedded wife. Another individual in the Hunters Group pointed out that village inhabitants harvest black sticks to make tools for hunting and weapons for war.

Further, a local from the Vigilante Group explained that:

There are some plants obtained from the park and on village land which are important to the local people for medicinal and spiritual use. We use the Nkeng plant to make peace in the event of land disputes, Nasamba and Wokaka to treat stomach pain, and Quini sticks to cure Malaria. The Gahga yowo uses the Seke-seke and Akom to inflict fever on persons who violate Bakweri taboos on the land. (Field data, 2017)

These modes of subsistence suggest, to an extent, that the Bakweri, within the limits of forest resources available to them, continue their culturally-embedded practices on the land, in 
ways consistent with their customs. Another important means of subsistence land-use is through farming in communal lands. These are lands located a few kilometers away from protected area boundary lines of MCNP and generally used by local people (they perceive such lands as a constituent part of village land).

Here, crops like yams and a wide range of greens, such as bitter-leaf and sweet bitter-leaf, are cultivated for subsistence needs. Other crops grown for subsistence, although partly sold in markets, are plantain, banana, pear, lime, orange, and Raphia palm used for thatches and the extraction of a substance 'palm wine' consumed at home as a traditional drink during ceremonial events. Wild snails are another forest product, of high nutritive value in protein and carbohydrates, used for subsistence consumption in households. They are often hunted from the forest by locals working 20 hours a week on average searching and gathering. In recent years, many locals have engaged in practices of snail farming in peripheral zones of MCNP, which play an important role in reducing pressure in protected areas. They also promote livelihood development, enabling hunters to produce snails faster and generate income through trading.

\section{Discussion}

The above narratives among Bakweri individuals are what we see as evidence of cultural continuity in spite of state control on the land. So, what do these findings imply for the broader debate about park governance? What we do know is that the people-park discourse has been critical of state-led resource management for distancing people and their cultures from protected areas (Muhumuza and Balkwill, 2013; West et al., 2006). The people-park discourse has equally raised concerns about local communities that become victims of state plans for conserving forestlands in Africa (Hartter, 2007; Joppa et al., 2008; West et al., 2006). We, however, argued in this article that very little assessment exists to examine how cultural practices persist in situations where park governance does not entirely favor the livelihoods of local/indigenous people. We assessed that a closer look at the 'anonymous' or often unaccountable mediums by which locals use parks and their peripheral zones can be useful for understanding how cultures persist in spite of gaps in the state conservation of parks. Our analysis suggests that even under restrictions by the state management of MCNP, the Bakweri continue to enact their culturally-embedded subsistence practices on the land even a decade after the establishment of the park. Three factors explain this level of attachment to the land.

Firstly, we observed that the focus groups collectively act to secure livelihood assurances on the land. Most respondents were aware of ways to attain cultural needs without the involvement of park officials. The analysis indicates that even though state plans for protected areas might hinder the cultural needs of societies (Muhumuza and Balkwill, 2013; West et al., 2006), people tend to find other ways to hold onto their cultural use of the land. Because the state management plan for MCNP supports locals mainly when they comply with state laws (Nebasifu and Atong, 2019a), the focus groups turn to rely on ritually relevant practices to manage situations that are beyond the control of humans. They do so by requesting the intervention of ancestral spirits and deities to free sick persons from intricate illnesses, to guard villages against external hostilities, and to prevent natural disasters from damaging crops on the land. 
Secondly, the interviews suggest that the remoteness of a village shapes one's attachment to place. Joppa et al. (2008) found that human activity significantly accounted for damage in Africa's Congo Basin forests. In contrast, we identified a difference complementary to remote areas that were hard for park officials to reach. For example, in most of the villages of Bomboko, local land users had maintained enduring traditions on the land. They used the land in ways that promoted a 'nonconventional' type of conservation (i.e. avoiding the damage of animals of spiritual value to the Bakweri, such as the elephant). An explanation for this level of attachment might be less influx of persons from elsewhere into these villages. This helps safeguard cultural practices from being altered by the interference of state laws on land-use. This was in contrast to localities in semi-urban areas that appear more accessible to persons from other regions of the country.

Thirdly, previous literature (Taubert and Pretzsch, 2007) reported the ability for people to sustain their attachment to the forest by prohibiting sharing of secrets about the forest to members of the society such as women, children, and strangers. The Bakweri case, however, suggests that such attachment can equally be influenced by people's sense of belonging in a group: an observation that relates to the preservation of secret knowledge. Along these lines of thinking, parents in Bakweri society acquire and transmit ancestral knowledge from one generation to another. Such knowledge can be about the use of valuable medicinal plants that are located in remote parts of the park and the secrecy of shrines in peripheral forests, whose details are often untold to strangers.

\section{Conclusion}

Our article focused on narratives about cultural continuity in and around a protected area. We indicated the inadequacy of the people-park literature to show how local/indigenous people persist in maintaining their culture despite state management that does not favor them. We used the example of the Bakweri around MCNP to explore how they continue their traditions through ritual practices and the subsistent use of the forest. The results showed that in this example, factors of village remoteness, collective assurances, and a sense of belonging to a group help to enhance the reciprocal attachment of people to the land. This analysis partially bridges gaps of cultural continuity in cases where people-park relations exist with lapses, and where scholars often examine problems of land-use in regimes without much attention to people's cultural persistency on the land. The findings also suggest that the state management of protected areas can be partially bounded where even when it does not give space for the customary use of the land, and people develop their own space for attachment to the land. In this instance, people tend to rely on deeply rooted practices for needs that are hard to attain from the state. They often do so in rather anonymous situations, which warrants further examination for us to better understand cultural continuities in situations of park governance. 
${ }^{1}$ Less than $(<)$ and greater than $(>)$ are used to show the estimated population size for a village, where 612 and 1-6 represents the distance range between a village and park boundary, used when the precise distance is unknown.

\section{Acknowledgment}

We acknowledge the financial support the lead author obtained from the Graduate School at the University of Lapland, which enabled us to perform our research tasks. We also appreciate the co-author who assisted in conducting interviews. We want to thank Professor Florian Stammler at the Arctic Centre in Rovaniemi and Professor Seija Tuulentie at the Natural Resources Institute Finland (LUKE) for supervising the lead author. We owe much debt to the chiefs and their villagers who generously contributed time to respond to our inquiries. We thank the staff of the Environment and Rural Development Foundation (ERuDeF) for supervising our fieldwork in Cameroon. Our gratitude to the staff of Mount Cameroon National Park (MCNP) Service, Cameroon's Ministry of Forestry and Wildlife, and the Arctic Centre in Rovaniemi, who provided office space for us. We would like to thank Peter Loovers and Professors Samuel Ndonwi and Lum Suzanne for checking the language of this article, and the editors and reviewers for their useful comments.

\section{References}

Ajonina, S.A., Terence, O.E., and Atud, C. (2017). The role of traditional taboos and custom as complementary tools in wildlife conservation within Mount Cameroon National Park Buea. International Journal of Natural Resource Ecology and Management, 2(3), 60-68.

Akem, E.S. (2019). Ethnoecology of bushfires in and around the Mount Cameroon National Park. International Journal of Current Research, 11(3), 2284-2289.

Appiah-Opoku, S. (2011). Using protected areas as a tool for biodiversity conservation and ecotourism: a case study of Kakum National Park in Ghana. Society \& Natural Resources, 24(5), 500-510.

Ardener, E. (1996). Kingdom on Mount Cameroon: Studies in the history of the Cameroon coast $1500-$ 1970. Oxford: Berghahn Books.

Byers, B.A., Cunliffe, R.N., and Hudak, A.T. (2001). Linking the Conservation of Culture and Nature. A Case Study of Sacred Forests in Zimbabwe. Human Ecology, 29(2), 187-218.

Charlotte, C. N. (2014). Management plan of the Mount Cameroon national park and its peripheral zone. Cameroon (Vol. 3). Cameroon. http://documents.worldbank.org/curated/en/290571468007177234/pdf/E23260V30REPLA00Bo x391426B00PUBLICO.pdf

Doody, O., Slevin, E., and Taggart, L. (2012). Preparing for and conducting focus group interviews. British Journal of Nursing, 22(3), 170-173.

Hartter, J. (2007). Landscape Change around Kibale National Park, Uganda: Impacts on Land Cover, Land use, and Livelihoods. [Doctoral dissertation, University of Florida, USA]. University of Florida Digital Collections.

The African Commission on Human and Peoples' Rights (ACHPR) and International Work Group for Indigenous Affairs (IWGIA). (2005). Report of the African Commission's working group of experts on indigenous populations/communities. African Commission on Human and Peoples' Rights (ACHPR), Gambia. 
Jabeen, A., Khan, M.A., Ahmad, M., Zafar, M., and Ahmad, F. (2009). Indigenous uses of economically important flora of Margallah Hills National Park, Islamabad, Pakistan. African Journal of Biotechnology, 8(5), 763-784.

Joppa, L.N., Loarie, S.R., and Pimm, S.L. (2008). On the protection of protected areas. Proceedings of the National Academy of Sciences, 105(18), 6673 - 6678.

Muhumuza, M. and Balkwill, K. (2013). Factors affecting the success of conserving biodiversity in National Parks: a review of case studies from Africa. International Journal of Biodiversity, 2013, 1-20.

Nebasifu, A.A. and Atong, N.M. (2019a). Rethinking Institutional Knowledge for Community Participation in Co-management. Sustainability, 11(20), 1-19.

Nebasifu, A.A. and Atong, N.M. (2019b). Expressing Agency in Antagonistic Policy Environments. Environmental Sociology, 6(2), 154-165.

Neh, M.E. (1989). Phonology of Mokpwe. [Doctoral dissertation, University of Yaoundé, Cameroon]. http://citeseerx.ist.psu.edu/viewdoc/download?doi=10.1.1.1031.8640\&rep=rep1\&type=pdf

Ngang, F.D., Azinwie, A.G., Tellen, A.V., and Nchang, C.L. (2018). Community forest use and dependence for livelihoods in Fako Division, South West Region of Cameroon. Greener Journal of Agronomy, Forestry and Horticulture, 5(1), 1-11.

Pemunta, N.V. (2018). The logic of benevolent capitalism: the duplicity of Sithe Global Sustainable Oils Cameroon land grab and deforestation scheme as sustainable investment. International Journal of Global Environmental Issues, 17(1), 80-109.

Plotkin, R. (2018). Tribal Parks and Indigenous Protected and Conserved Areas. Lessons Learned from B.C. Example. Vancouver, BC, Canada.

Republic of Cameroon. (1994). Law no. 94/01 of 20th January 1994 to lay down forestry, wildlife, and fisheries regulations. Republic of Cameroon, Yaounde, Cameroon.

Rist, P., Rassip, W., Yunupingu, D., Wearne, J., Gould, J., Dulfer-Hyams, M., Bock, E., and Smyth, D. (2019). Indigenous protected areas in Sea Country: Indigenous-driven collaborative marine protected areas in Australia. Aquatic Conservation: Marine and Freshwater Ecosystems, 29(S2), 138-151.

Taubert, B. and Pretzsch, J. (2007). Cultural influence of forest perception and forest use among the Tiriki community in west Kenya. Paper presented at the Conference on International Agricultural Research for Development, October 9-11, 2007, Institute of International Forestry and Forest Products, Germany.

West, P., Igoe, J., and Brockington. D. (2006). Parks and people: the social impact of protected areas. Annual Review of Anthropology, 35(1), 251-277.

Wily, L.A. (2011). Whose land is it? The status of customary land tenure in Cameroon. Centre for Environment and Development, Cameroon. https://www.fern.org/fileadmin/uploads/fern/Documents/cameroon eng internet.pdf

Zurba, M., Beazley, K.F., English, E., Buchmann-Duck, J. (2019). Indigenous Protected and Conserved Areas (IPCAs), Aichi Target 11 and Canada's Pathway to Target 1: Focusing Conservation on Reconciliation. Land, 8(10), 1-20. 